\title{
PENGUATAN PENDIDIKAN KARAKTER MELALUI KEGIATAN PEMBELAJARAN, HABITUASI, DAN EKSTRAKURIKULER DI MADRASAH/SEKOLAH
}

\author{
Oleh Aji Sofanudin dan Wahab \\ Peneliti Bidang Pendidikan Agama dan Keagamaan
}

\section{Executive Summary}

Penelitian "Survei Karakter Peserta Didik MA dan SMA" ini diselenggarakan oleh Puslitbang Pendidikan Agama dan Keagamaan yang berkolaborasi dengan Balai Litbang Agama Jakarta, Balai Litbang Agama Semarang, dan Balai Litbang Agama Makassar. Penelitian ini merupakan survei nasional karakter peserta didik di 34 Provinsi. Pengambilan sampel ada di 169 Kabupaten/Kota di Indonesia.

Balai Litbang Agama Semarang melakukan pengumpulan data di empat provinsi, yaitu: Jawa Timur, Daerah Istimewa Yogyakarta, Bali, dan Nusa Tenggara Barat. Jumlah sampel penelitian sebanyak 1.420 peserta didik kelas XI yang tersebar di 144 SMA dan 760 peserta didik kelas XI yang tersebar di 76 MA. Jumlah sampel yang dikumpulkan oleh Tim Peneliti Balai Litbang Agama Semarang sebanyak 2.180 peserta didik kelas XI (220 satuan pendidikan) atau 18,9 \% dari sampel nasional.

Survei ini bertujuan untuk mengukur kualitas karakter peserta didik MA dan SMA yang terdiri atas karakter religiusitas, nasionalisme, kemandirian, gotong royong, dan integritas di empat provinsi tersebut. Populasi dalam penelitian ini adalah seluruh peserta didik kelas XI pada MA dan SMA, baik negeri maupun swasta di empat provinsi tersebut.

Penelitian ini secara umum menunjukkan hasil sebagai berikut. Pertama, kualitas karakter peserta didik pada MA dan SMA di empat provinsi mencapai rata-rata skor 3,41 atau masuk pada kategori "sangat baik". Jawa Timur menempati urutan pertama dengan tingat karakter tertinggi mencapai 3,46 (sangat baik), disusul DIY memperoleh nilai 3,41 (sangat baik), NTB memperoleh nilai 3,41 (sangat baik), dan Bali memperoleh nilai 3,37 (sangat baik).

Kedua, kualitas karakter peserta didik secara berurutan adalah sebagai berikut: karakter nasionalisme $(3,53)$, religiusitas $(3,49)$, integritas $(3,39)$, kemandirian $(3,34)$, 
dan gotong royong $(3,32)$. Tiga karakter urutannya sama di empat provinsi, yaitu karakter nasionalisme, religiusitas dan integritas. Dua karakter yang lain yaitu gotong royong dan kemandirian berbeda urutan. Pada provinsi DIY dan Bali, karakter kemandirian menempati posisi terendah, sedangkan pada provinsi Jawa Timur dan NTB, karakter gotong royong menempati posisi terendah.

Ketiga, dalam kaitan dengan karakter religiusitas, terdapat respon dari beberapa peserta didik yang berpotensi melahirkan sikap eksklusivitas beragama. Hal ini ditunjukkan bahwa dari 2.180 peserta didik, terdapat 10,05\% yang menyatakan "tidak setuju/sangat tidak setuju" bergaul dengan tetangga berbeda agama. Persentase peserta didik yang "tidak setuju/sangat tidak setuju" untuk bekerjasama dengan orang berbeda agama mencapai $13,21 \%$. Sedangkan untuk pernyataan "saya membenci kekerasan bernuansa agama" terdapat 9,68\% peserta didik yang menyatakan "tidak setuju/sangat tidak setuju”.

Keempat, walaupun karakater nasionalisme peserta didik sudah sangat baik, terdapat beberapa hal yang masih perlu dilakukan penguatan pada indikator sebagai berikut: (1) Terkait dengan pakaian batik yang merupakan pakaian khas Indonesia masih terdapat 9,68\% peserta didik yang memberikan respon "tidak setuju/sangat tidak setuju" terhadap pernyataan "saya suka mengenakan baju batik"; (2) Terdapat 5,14\% yang menyatakan tidak lebih senang produk anak bangsa dibanding produk luar negeri; (3) Terdapat 30,55\% yang menyatakan "tidak setuju/sangat tidak setuju” jika sekolah memaksakan peserta didik menyanyikan lagu Indonesia Raya untuk melahirkan patriotisme.

Kelima, dalam kaitan dengan integritas peserta didik, terdapat 23,94\% yang menyatakan "setuju dan sangat setuju" tindakan mencontek pada saat tes atau ujian. Selanjutnya, terdapat $14,27 \%$ yang "setuju dan sangat setuju" meniru tugas yang dibuat oleh teman.

\section{Ditujukan kepada}

1. Menteri Koordinator Bidang Pembangunan Manusia dan Kebudayaan

2. Menteri Agama RI cq Direktorat Jenderal Pendidikan Islam

3. Menteri Pendidikan dan Kebudayaan RI cq Direktorat Jenderal Pendidikan Dasar dan Menengah 


\section{Kepala Kanwil Kementerian Agama Provinsi}

5. Kepala Dinas Pendidikan dan Kebudayaan Provinsi

\section{Isu Strategis}

Kementerian Pendidikan Nasional (2010) telah mengidentifikasi 18 nilai dalam pendidikan budaya dan karakter bangsa. Nilai tersebut bersumber dari agama, Pancasila, budaya, dan tujuan pendidikan nasional, yaitu: religius, jujur, toleransi, disiplin, kerja keras, kreatif, mandiri, demokratis, rasa ingin tahu, semangat kebangsaan, cinta tanah air, menghargai prestasi, bersahabat/ komunikatif, cinta damai, gemar membaca, peduli lingkungan, peduli sosial, dan tanggung jawab.

Pada tahun 2017 melalui Gerakan Penguatan Pendidikan Karakter (PPK), Kementerian Pendidikan dan Kebudayaan "memeras" 18 nilai tersebut menjadi lima nilai utama karakter yang saling berkaitan yaitu: (1) religiusitas, (2) nasionalisme, (3) mandiri, (4) gotong royong dan (5) integritas. Secara operasional ada dalam Peraturan Menteri Pendidikan dan Kebudayaan Nomor 20 Tahun 2018 tentang Penguatan Pendidikan Karakter pada Satuan Pendidikan Formal.

\section{Pengantar}

Pendidikan karakter merupakan bagian esensial dalam proses pendidikan. Undang-undang Dasar (UUD) 1945 pasal 31 ayat 3 menyebutkan, pemerintah mengusahakan dan menyelenggarakan satu sistem pendidikan nasional yang meningkatkan keimanan dan ketakwaan serta akhlak mulia dalam rangka mencerdaskan kehidupan bangsa yang diatur dengan undang-undang. Undang-undang Nomor 20 tahun 2003 menyebutkan bahwa tujuan pendidikan untuk berkembangnya potensi peserta didik agar menjadi manusia yang beriman dan bertakwa kepada Tuhan yang Maha Esa, berakhlak mulia, sehat, berilmu, cakap, kreatif, mandiri dan menjadi warga negara yang demokratis serta bertanggung jawab.

Kementerian Pendidikan dan Kebudayaan menerapkan tiga pendekatan penguatan pendidikan karakter, yaitu pendidikan karakter berbasis pembelajaran di kelas, habituasi atau pembiasaan di sekolah, dan berbasis kegiatan ekstrakurikuler. 


\section{Kebijakan yang Ada}

Dasar hukum pendidikan karakter adalah sebagai berikut:

1. Undang-undang Nomor 20 Tahun 2003 tentang Sistem Pendidikan Nasional

2. Peraturan Pemerintah Nomor 55 Tahun 2007 tentang Pendidikan Agama dan Pendidikan Keagamaan

3. Peraturan Pemerintah Nomor 87 tahun 2017 tentang Penguatan Pendidikan Karakter

4. Permendikbud Nomor 20 tahun 2018 tentang Penguatan Pendidikan Karakter pada Satuan Pendidikan Formal

\section{Rekomendasi Kebijakan}

1. Kementerian Koordinator Bidang Pembangunan Manusia dan Kebudayaan perlu terus menggelorakan semangat gotong royong dan kemandirian bangsa Indonesia

2. Kementerian Agama RI dan Kemendikbud RI perlu terus meningkatkan strategi penguatan pendidikan karakter peserta didik terutama penguatan pendidikan karakter kemandirian dan gotong royong

3. Kementerian Agama RI cq Direktorat Jenderal Pendidikan Islam perlu menyusun pedoman pelaksanaan dan pengembangan kompetensi pengawas dan guru berupa pelatihan mengembangkan silabus dan RPP dalam rangka penguatan pendidikan karakter

4. Menteri Pendidikan dan Kebudayaan RI cq Direktorat Jenderal Pendidikan Dasar dan Menengah perlu terus melakukan supervisi terhadap pelaksanaan penguatan pendidikan karakter di setiap sekolah

5. Kepala Kanwil Kementerian Agama Provinsi perlu melakukan penguatan terhadap materi moderasi beragama di madrasah dan sekolah

6. Kepala Dinas Pendidikan dan Kebudayaan Provinsi untuk menyusun regulasi terkait kewajiban pakaian seragam sekolah produk daerah setempat (batik, lurik, sasirangan, songket, jumput, dll)

7. Pihak sekolah/madrasah dapat melakukan penguatan pendidikan karakter melalui tiga hal yaitu (1) pembelajaran di kelas, (2) pembiasaan di sekolah/madrasah dan (3) kegiatan ekstrakurikuler. 


\section{Referensi}

Policy brief ini disusun berdasarkan laporan hasil penelitian "Survei Karakter Peserta Didik MA dan SMA" yang dilakukan oleh Umi Muzayanah (Ketua Tim) dengan anggota peneliti dari Balai Litbang Agama Semarang sebagai berikut: Wahab, Mulyani Mudis Taruna, Aji Sofanudin, Mukhtaruddin, AM Wibowo, Siti Muawanah, Nugroho Eko Atmanto, Ahmad Muntakib, Isnanto 